JURNAL SEHAT MASADA $\quad$ VOLUME $\quad$ XV NOMOR $1 \quad$ Januari $2021 \quad$ ISSN : 1979-2344

\title{
KUNJUNGAN ANTENATAL CARE DINTINJAU DARI PENGETAHUAN IBU HAMIL TENTANG TANDA BAHAYA KEHAMILAN DI PUSKESMAS BATU AJI KOTA BATAM TAHUN 2019
}

\author{
Ika Novita Sari \\ Prodi Sarjana Keperawatan, Fakultas Kedokteran, Universitas Batam \\ ikanovitasari@univbatam.ac.id
}

\begin{abstract}
ABSTRAK
Setiap kehamilan dapat memiliki potensi dan membawa resiko bagi ibu sampai meimbulkan kematian ibu dan anak, oleh karena itu deteksi dini oleh tenaga kesehatan dan masyarakat merupakan kunci keberhasilan dalam penurunan angka kematian ibu dan bayi yang dilahirkannya. Tujuan penelitian ini adalah untuk mengetahui hubungan pengetahuan ibu hamil tentang tanda bahaya kehamilan. Penelitian ini menggunakan metode cros secsional dengan jumlah responden 35 ibu hamil. Analisis statsitik menggunakan uji chi square. Hasil penelitian menunjukkan mayoritas ibu hamil melakukan kunjungan antenatal care yang sesuai sebanyak $80 \%$ dan mayoritas ibu hamil memiliki pengetahuan baik sebanyak $54.3 \%$ serta ada hubungan antar pengetahuan ibu hamil tentang tanda bahaya kehamilan dengan kunjungan antenatal care di Puskesmas Batu Aji Kota Batam dengan $p$ value 0.002.
\end{abstract}

Kata Kunci : Kunjungan Antenatal Care, Tingkat Pengetahuan tentang tanda bahaya kehamilan

\begin{abstract}
Every pregnancy can have the potential and carry risks for the mother to cause the death of both mother and child, therefore, early detection by health personnel and the community is the key to success in reducing the mortality rate for mothers and babies born to them. The purpose of this study was to determine the relationship between the knowledge of pregnant women about the danger signs of pregnancy. This study used a cross sectional method with 35 respondents as respondents. Statistical analysis using the chi square test. The results showed that the majority of pregnant women made appropriate antenatal care visits as many as $80 \%$ and the majority of pregnant women had good knowledge as much as $54.3 \%$ and there was a relationship between the knowledge of pregnant women about the danger signs of pregnancy with antenatal care visits at Batu Aji Health Center, Batam City with a $p$ value of 0.002
\end{abstract}

Keywords: Antenatal Care Visits, Knowledge Level about pregnancy danger signs

\section{PENDAHULUAN}

Program kesehatan Ibu dan bayi merupakan salah satu prioritas Kementrian Kesehatan dan keberhasilan program KIA menjadi salah satu indicator utama dalam Rencana Pembangunan Jangka Panjang
Nasional (RPJPN) 2005-2025. Tingginya Angka Kematian (AKI) di Indonesia membuat pemerintah menempatkan upaya penurunan AKI sebagai program prioritas dalam pembangunan kesehatan (WHO, 2012). Sementar itu, angka kematian ibu dan bayi 
JURNAL SEHAT MASADA VOLUME XV

merupakan tolak ukur dalam menilai derajat kesehatan suatu bangsa, oleh karena itu, pemerintah sangat menekankan untuk menurunkan angka kematian ibu dan bayi melalui program-program kesehatan (Depkes RI, 2013).

Pada tahun 2014 AKB di Indonesia mencapai 25 per 1.000 kelahiran hidup. Bila dibandingkan dengan Malaysia, Filipina dan Singapura, angka tersebut lebih besar dibandingkan dengan angka dari negara-negara tersebut dimana AKB Malaysia 7 per 1.000 kelahiran hidup, Filipina 24 per 1.000 kelahiran hidup dan Singapura 2 per 1.000 kelahiran hidup. Berdasarkan data dari WHO, Angka Kematian Ibu (AKI) di Indonesia masih tinggi dibandingkan dengan negara ASEAN lainnya. AKI di Indonesia menurut Survei Demografi dan Kesehatan Indonesia (SDKI) tahun 2012 sebesar 359 per 100.000 kelahiran hidup meningkat dibandingkan hasil SDKI tahun 2007 sebesar 228 per 100.000 kelahiran hidup.

Menurut WHO (2018), setiap hari, 830 ibu di dunia meninggal akibat penyakit/komplikasi terkait kehamilan dan persalinan dan di Indonesia 38 ibu sedangkan berdasarkan AKI 305. Komplikasi kehamilan merupakan merupakan salah satu penyebab masih tingginya angka kematian ibu (AKI) di Indonesia sampai saat ini, yaitu perdarahan sebanyak $28 \%$ dan keracunan kehamilan (eklamsi) sebanyak 24\%. Tanda-tanda bahaya pada kehamilan merupakan suatu pertanda telah terjadinya masalah yang serius pada ibu
NOMOR $1 \quad$ Januari 2021

ISSN : 1979-2344

hamil atau janin yang di kandungnya. Berdasarkan penelitian, telah diakui saat ini bahwa setiap kehamilan dapat memiliki potensi dan membawa resiko bagi ibu (Sembaring R. 2010). Oleh karena itu deteksi dini oleh tenaga kesehatandan masyarakat tentang adanya factor risiko dan komplikasi, serta penanganan yang adekuat sedini mungkin, merupakan kunci keberhasilan dalam penurunan angka kematian ibu dan bayi yang dilahirkannya (Sumarni, Rahma, Ikhsan M, 2014).

Antenatal Care (ANC) sebagai salah satu upaya penapisan awal dari factor resiko kehamilan. Menurut WHO antenacal care selama kehamilan untuk mendeteksi dini terjadinya resiko tinggi terhadap kehamilan dan persalinan juga dapat menurunkan angka kematian ibu dan memantau keadaan janin. Apabila tiap wanita hamil bersedia untuk melakukan pemeriksaan kehamilannya, bertujuan untuk mendeteksi kelainan-kelainan yang mungkin ada atau akan timbul pada kehamilan tersebut diatasi sebelum berpengaruh tidak baik terhadap kehamilan tersebut dengan melakukan pemeriksaan antenatal care (Wiknjosastro, 2010).

ANC merupakan pelayanan kesehatan oleh tenaga professional yang diberikan kepada ibu selama masa kehamilan yang dilaksanakan sesuai dengan standar pelayanan antenatal. Frekuensi kunjungan 4 kali selama kehamilan, yaitu 1 kali pada trimester pertama, 1 kali pada trimester ke dua dan 2 kali pada trimester ketiga. Pemeriksaan medis dalam 
JURNAL SEHAT MASADA VOLUME XV

pelayanan antenatal meliputi anamnesis, pemriksaan fisik, diagnosis, pemeriksaan obstetric dan pemeriksaan diagnosis penunjang (Kemenkes RI, 2014)

Berdasarkan data riset Kesehatan Dasar (Riskesdas) tahun 2013 diketahui bahwa proporsi ibu hamil yang melakukan pemeriksaan kehamilan sebanyak 95,4\%, sedangkan yang tidak melakukan pemeriksaan sebanyak 4,6\%. Jumlah ibu yang melakukan pemeriksaan tertinggi di Bali yaitu 99,6\% dan terendah di Papua yaoti 71,7\%. Cakupan ANC K4 di Indonesia sebesar 70,4\%. Angka cakupan ANC K4 tertinggi di Bali yaitu 80,3\%, sedangkan ANC K4 terendah di Papua sebesar $56,3 \%$.

Maih rendahnya kunjungan $\mathrm{ANC}$, salah satunya mungkin disebabkan karena pemahaman tentang kehamilan dan masalah dalam kehamilan masih kurang, sehingga masih ditemukan ibu hamil yang tidak patuh melakukan kunjungan pemeriksaan kehamilan secara teratur. Kurangnya pengetahuan ibu tentang tanda bahaya kehamilan, persalinan dan nifas dapat menyebabkan ibu tidak dapat melakukan identifikasi terhadap tanda-tanda yang Nampak sehingga tidak dapat melakukan antisipasi secara dini. Penelitian ini bertujuan untuk mengetahui hubungan pengetahuan ibu hamil tentang tanda bahaya kehamilan.

\section{METODE}

\section{a. Hasil}

Penelitian ini menggunakan metode survey analitik, dengan desain penelitian yang Jurnal Penelitian Kesehatan STIKes Dharma Husada Bandung
ISSN : 1979-2344

digunakan adalah Crossectional. Variabel independent adalah pengetahuan ibu tentang tanda bahaya kehamilan, sedangkan variable dependen adalah kunjungan ANC. Populasi dalam penelitian ini adalah seluruh ibu hamil yang melakukan kunjungan pemeriksaan kehamilan di Puskesmas Batu Aji Kota Batam pada bulan Januari-Maret 2019 sebanyak 182 ibu hamil. Tekhnik sampling menggunakan Accidental Sampling. Analisa yang digunakan menggunakan Analisa univariat yaitu dilakukan untuk menjelaskan karakteristik masing-masing variable yang diteliti dengan menggunakan distribusi frekuesi dalam ukuran persentase dan bivariat untuk menilai hubungan antara variable dengan uji chi square, pada tingkat kepercayaan $95 \%$.

\section{HASIL DAN PEMBAHASAN}

\section{a. Hasil}

Sampel yang digunakan sebanyak $35 \mathrm{ibu}$ hamil yang melakukan ANC di Puskesmas Batu Aji.

\section{Tabel 1 Distribusi Frekuensi Kunjungan Antenatal Care}

\begin{tabular}{lcc}
\hline $\begin{array}{c}\text { Kunjungan } \\
\text { Antenatal Care }\end{array}$ & $\mathbf{f}$ & \% \\
\hline Sesuai & 28 & 80 \\
\hline Tidak Sesuai & 7 & 20 \\
\hline Total & 35 & 100 \\
\hline
\end{tabular}

Berdasarkan tabel 1, ibu hamil yang melakukan kunjungan ANC dengan sesuai lebih banyak $(80 \%)$. 
Tabel 2 Distribusi Frekuensi Pengetahuan Ibu Hamil Tentang Tanda Bahaya Kehamilan

\begin{tabular}{lcc}
\hline $\begin{array}{c}\text { Pengetahuan } \\
\text { Ibu Hamil }\end{array}$ & f & \% \\
\hline Baik & 19 & 54.3 \\
\hline Kurang & 16 & 45.7 \\
\hline Total & 35 & 100 \\
\hline
\end{tabular}

Berdasarkan tabel 2, pengetahuam ibu hamil tentang tanda bahaya kehamilan kategori baik,sedikit lebih banyak $(54,3 \%)$ dibanding kategori kurang $(45,7 \%)$.

Tabel 3 Hubungan Pengetahuan Ibu Hamil Tentang Tanda Bahaya Kehamilan dengan Kunjungan Antenatal Care

\begin{tabular}{lcccccccc}
\hline \multirow{2}{*}{$\begin{array}{c}\text { Pengetahuan } \\
\text { Ibu Hamil }\end{array}$} & \multicolumn{4}{c}{ Kunjungan ANC } & \multicolumn{2}{c}{ Total } & \multirow{2}{*}{ p value } \\
\cline { 2 - 7 } & $\mathbf{f}$ & $\mathbf{\%}$ & $\mathbf{f}$ & $\mathbf{\%}$ & $\mathbf{f}$ & $\mathbf{\%}$ & \\
\hline Baik & 19 & 54.3 & 0 & 0 & 19 & 54.3 & \multirow{2}{*}{0,002} \\
\hline Kurang & 9 & 25.7 & 7 & 20 & 16 & 45.7 & \\
\hline Total & $\mathbf{2 8}$ & $\mathbf{8 0}$ & $\mathbf{7}$ & $\mathbf{2 0}$ & $\mathbf{3 5}$ & $\mathbf{1 0 0}$ & \\
\hline
\end{tabular}

Berdasarkan tabel 3, Ibu hamil dengan pengetahuan baik dan patuh dalam melakukan kunjungan ANC (54,3\%), sedangkan ibu hamil dengan pengetahuan baik namun tidak patuh melakukan kunjungan ANC (0\%). Ibu hamil dengan pengetahuan kurang dan tidak patuh melakukan kunjungan ANC (20\%) namun ada pula ibu hamil dengan pengetahuan kurang tapi patuh melakukan kunjungan ANC (25,7\%).

\section{b. Pembahasan}

Dari 35 responden mayoritas kunjungan antenatal care sesuai sebanyak 28 responden $(80 \%)$. Penelitian ini sejalan dengan penelitian menyatakan mayoritas kunjungan antenatal care ibu hamil baik atau sesuai. Penelitian ini tidak sejalan dengan penelitian yang dilakukan oleh Lina Oktavia (2018), Suryani dkk (2017) dan Galuh Candra Swandari (2017) yang yang dilakukan oleh Sumarni (2014) yang

menyatakan mayoritas kujungan antenatal care ibu yang kurang baik.

Berdasarkan hasil penelitian didapatkan pengetahuan ibu hamil tentang tanda bahaya kehamilan baik sebanyak 19 responden $(54,3 \%)$. Penelitian ini sejalan dengan penelitian yang dilakukan oleh Lina Oktavia (2018); Galuh Candra Swandari (2017) dan Dian pratitis (2013) yang menyatakan mayoritas respondennya berpengetahuan baik. Namun penelitian ini tidak sejalan dengan penelitian; Suryani dkk (2017) dan Sumarni (2014) yang menyatakan pengetahuan ibu hamil mayoritas kurang.

Berdasarkan perhitungan analisis dengan uji Chi-Square diketahui bahwa nilai $p$ value sebesar 0,002 karena nilai p lebih kecil dari $0,05(0,004<0.05)$ maka da terdapat hubungan pengetahuan dengan kunjungan ANC di Puskesmas Batu Aji Kota Batam. Artinya semakin baik pengetahuan ibu hamil tetang 
JURNAL SEHAT MASADA VOLUME XV

tanda-tanda bahaya kehamilan akan semakin mau memeriksakan kehamilannya secara teratur kepada petugas kesehatan selama periode kehamilannya.

Hasil penelitian ini sejalan dengan penelitian oleh Adhika Wijayanti (2016), Sumarni (2014), Lina Oktavia (2018), Suryani dkk (2017) yang menyatakan ada hubungan antara pengetahuan ibu tentang tanda bahaya kehamilan dengan kunjungan Antenatal Care.

Tingkat pengetahuan respinden tentang antenatal care diperoleh dari pengalaman tentang kehamilan, tingkat pendidikan, lingkungan dan sebagainya. Pengalaman tentang kehamilan dapat diperoleh dari kehamilan yang dialami responden sendiri atau mendapat informasi dari pengalaman orang lain. Ibu yang berpengetahuan baik lebih banyak memanfaatkan pelayanan antenatal, hal ini disebabkan ibu yang berpengetahuan baik peduli dengan kesehatannya dan terdapat perhatian terhadap keadaan kehamilannya. Menurut Bloom dan Notoatmodjo mengatakan bahwa pengetahuan merupakan domain yang sangat penting untuk terbentuknya tindakan seseorang.

Penelitian ini juga sesuai dengan teori Green dalam Notoatmodjo (2012) untuk menunjukkan sikap menjadi perbuatan nyata diperluka factor pendukung atau kondisi yang memungkinkan. Fanktor yang mendukunh adalah : (1) factor predisposisi (pengetahuan, sikap, keyakinan persepsi); (2) factor pendukung (akses pada pelayanan kesehatan, keterampilan dan adanya referensi); (3) factor
NOMOR $1 \quad$ Januari 2021

ISSN : 1979-2344

pendorong terwujud dalam bentuk dukungan dari keluarga, tetangga dan tokoh masyarakat.

\section{KESIMPULAN}

1. Sebagian besar kunjungan antenatal responden di Puskesmas Batu Aji Kota Batam adalah sesuai (80\%)

2. Sebagian besar responden di Puskesmas Batu Aji Kota Batam memiliki pengatuhan baik tentang tanda bahaya kehamilan (54.3\%)

3. Ada Hubungan antara pengetahuan ibu hamil tentang tanda bahaya kehamilan dengan kunjungan antenatal care

\section{DAFTAR PUSTAKA}

1. Depkes RI. Sistem Kesehatan Nasional.Jakarta: Kementrian kesehatan Indonesia. 2009

2. Kemenkes RI. Buku Saku Pelayanan Kesehatan Ibu di Fasilitas Kesehatan Dasar dan Rujukan, Pedoman Bagi Tenaga Kesehatan. Jakarta: Kementerian Kesehatan Republik Indonesia; 2014.

3. Kemenkes RI. Riset Kesehatan Dasar (Riskesdas) Tahun 2013 dalam Angka. Jakarta; 2014

4. Notoatmodjo, S. Promosi Kesehatan dan Ilmu Perilaku. Jakarta: Rhineka Cipta. 2012

5. Oktavia, Lina. Kunjunagan Antenatal Care (ANC) ditinjau dari Tingkat Pengetahuan Ibu Hamil Tentang Tnada Bahaya Kehamilan. Jurnal Aisyah : Jurnal Ilmu Kesehatan. Vol. 3 No 1 Juni 2018

6. Sembiring, R. (2010). Hubungan Anemia Dalam Kehamilan Dengan Kejadian Perdarahan Post Partum Di RSUP H. Adam Malik Medan. Jurnal D-III Kebidanan 
Mutiara Indonesia Vol. 2, No. 4, Desember 2010.

7. Sumarni, Rahma, Ikhsan M. (2014). Hubungan pengetahuan dan Sikap Ibu Hamil tentang Tanda Bahaya Kehamilan, Persalinan dan Nifas trehadap Perilaku ANC Puskesmas Latambaga Kabupaten Kolaka.

http://repository.unhas.ac.id/handle/123456 789/11094

8. Suryani, Sri Yun Utami, Yuli Suryanti. Hubungan Pengetahuan dan Dukungan dengan Kunjungan Antenatal Care pada Ibu Hamil di Wilayah Kerja Puskesmas Olak Kemang Kota Jambi Tahun 2015. Jurnal Bahan Kesehatan Masyarakat Vo. 1 No. 1 Edisi Mei 2017

9. WHO. Maternal Mortality. 2018. https://www.who.int/news-room/factsheets/detail/maternal-mortality

10.Wiknjosastro. (2010). Buku Panduan Praktis Pelayanan Kesehatan Maternal dan Neonatal, Edisi 1. Cet. 12. Jakarta: Bina Pustaka.

11.Wulandari, Darmayanti. Faktor-faktor yang Berhubungan dengan Kepatuhan Ibu Dalam Melakukan Kunjungan Antenatal Care di Wilayah Kerja Puskesmas Gabut Kabupaten Banjar, Kalimantan Selatan Tahun 2013. Jurnal Ilmu keperawatan dan Kebidanan Vol. 8 No.2. 2017 